\title{
A COMPARATIVE STUDY ON THE ADSORPTION PROPERTIES OF HEAVY METAL Cr IN LAKE SEDIMENT AND SOIL
}

\author{
JiANG, Y. ${ }^{1}-$ MA, X. L. ${ }^{1 *}-$ SUN, F. Y. ${ }^{1}-$ GUO, Y. X. ${ }^{1}-$ REN, L. J. ${ }^{1,2}-$ WANG, Y. J. ${ }^{1}-$ XIE, Z. L. ${ }^{3 *}$ \\ ${ }^{1}$ College of Resources and Environment, Jilin Agricultural University, Changchun 130118, \\ China \\ (phone: +86-138-3340-6073; fax: +86-0431-8453-1264) \\ ${ }^{2}$ Hebei puni testing technology co., LTD. Shijiazhuang 050011, China \\ (phone: +86-184-4398-4987; fax: +86-0431-8453-3110) \\ ${ }^{3}$ College of Plant Science, Jilin University, Changchun 130062, China \\ (phone: +86-151-3343-7521; fax: +86-0431-8516-6245) \\ *Corresponding authors \\ e-mail: 491277643@qq.com; phone: +86-180-0442-2753; fax: +86-0431-8453-1264 (Ma, X. L.) \\ e-mail:xiezl@jlu.edu.cn; phone: +86-139-4488-3685; fax: +86-0431-8783-6260 (Xie, Z. L.)
}

(Received 21 ${ }^{\text {st }}$ Oct 2020; accepted $19^{\text {th }}$ Jan 2021)

\begin{abstract}
Background: In order to study chromium (Cr) adsorption characteristics of sediment and shore soil in Xinlicheng Reservoir, Changchun City, Jilin Province, and to discuss the contribution of $\mathrm{pH}$ and organic matter adsorption, to explore the accumulation law of $\mathrm{Cr}$ in sediment and soil. (2) Methods: OECD Guideline106 equilibrium adsorption method was used in this study. The adsorption kinetics data of $\mathrm{Cr}$ in sediment and black soil were fitted by Elovich equation and parabolic diffusion equation. The Freundlich and D-R models were used to fit the adsorption thermodynamic data of $\mathrm{Cr}$. (3) Results: the isothermal adsorption curve of $\mathrm{Cr}$ by sediment and soil was "S" type, and $\mathrm{K}_{\mathrm{f}}$ sediment $>\mathrm{K}_{\mathrm{f}}$ soil. Thermodynamic parameters $\Delta \mathrm{G}<0, \Delta \mathrm{H}>0$, to demonstrate the adsorption of $\mathrm{Cr}$ was a spontaneous endothermic process, high temperature was beneficial to the spontaneity of adsorption; Within the $\mathrm{pH}$ range of the test, higher and lower $\mathrm{pH}$ values were not conducive to the adsorption of $\mathrm{Cr}$ by sediment and soil. With the increase of $\mathrm{pH}$, the adsorption capacity of $\mathrm{Cr}$ by soil and sediment first increased and then decreased. The adsorption amount of $\mathrm{Cr}$ in sediment and soil was the smallest at the $\mathrm{pH} 3$, and the adsorption amount was the largest at the $\mathrm{pH}$ 7. However, the difference between adsorption of $\mathrm{Cr}$ in the sediment under different $\mathrm{pH}$ was not significant ( $\mathrm{p}>0.05$ ), and the adsorption of $\mathrm{Cr}$ in the soil under different $\mathrm{pH}$ was significant $(\mathrm{p}<0.05)$. Compared with the soil and sediment without organic matter removal, the adsorption capacity of removing organic matter was significantly reduced $(\mathrm{p}<0.05)$, and the contribution rates of organic matter in sediment and soil to $\mathrm{Cr}$ were $50.38 \%$ and $48.40 \%$, respectively. Consequently, the content of organic matter played a key role in the adsorption of $\mathrm{Cr}$ in soil and sediment. Keywords: chromium, sediment and soil, adsorption characteristics, $p H$, organic matter content
\end{abstract}

\section{Introduction}

Heavy metals are non-biodegradable accumulative pollutants. The pollution problem is of global concern due to the toxic, persistent and non-degradable nature of excessive heavy metals in the environment. Chromium $(\mathrm{Cr})$, a common heavy metal, is characterized by bioaccumulation, high toxicity, carcinogenicity and mutagenicity, and can cause human cancer, severe diarrhea and kidney damage even at low concentrations (Song et al., 2019). Chromium is among the top hazardous substances priority of the Superfund (Jiang et al., 2018).

Heavy metals in soil mainly come from chemical fertilizers, pesticides, industrial wastewater and irrigation sewage and soil parent material. Chromium (VI) has strong 
fluidity, solubility and durability, which leads to polluted water, soil and sediment. Especially during heavy rain, pollutants enter the sediment in the riparian zone along with a large amount of soil, mud and sand, and sediment become the carrier, destination and storage place for various substances to migrate and transform in the water environment (Pan and Ding, 2011; Drinčić et al., 2018; Zhang et al., 2019). Through adsorption or chemical and physical combination, soil and sediment tend to accumulate heavy metals. They are both carriers and reservoirs for heavy metals, which play an important role in the migration of heavy metals.

In recent years, soil heavy metal pollution has received considerable attention by many researchers, and related studies have been published. These researches have shown that adsorption is an important process to control the presence of heavy metals in solid phase, including soil and sediment. Adsorption and desorption have been demonstrated closely related to soil properties, including $\mathrm{pH}$, organic matter, cation exchange capacity, and clay minerals, etc. A large number of studies have shown that $\mathrm{pH}$ is a main contributing factor. Zhang et al. (2017) studied the migration rule of $\mathrm{Cr}$ (VI) in the soil of vegetable base, and found that the initial concentration of heavy metal $\mathrm{Cr}$ and environmental $\mathrm{pH}$ value exerted an influence on the adsorption process of $\mathrm{Cr}(\mathrm{VI})$. Liu et al. (2018) proposed that the adsorption capacity of the adsorbent is closely related to $\mathrm{pH}$, which may change the existing form of $\mathrm{Cr}$, thus changing the leaching rate of heavy metals in the soils. Dong et al. (2009) studied the adsorption of $\mathrm{Cr}(\mathrm{VI})$ in moderately polluted farmland soil in northeast China and the effect of $\mathrm{pH}$ value on the adsorption, and found that the adsorption capacity of $\mathrm{Cr}(\mathrm{VI})$ in soil decreased against the increase of $\mathrm{pH}$, and the migration rate of $\mathrm{Cr}(\mathrm{VI})$ in soil and groundwater increased, which caused greater harm to the environment. Fonseca et al. (2009) studied the adsorption of $\mathrm{Cr}$ by acidic soils in Portugal and found that the mobility of $\mathrm{Cr}(\mathrm{VI})$ was low in acidic soils. In addition to soil $\mathrm{pH}$, soil organic matter is also one of the important properties that affect the availability of heavy metals. Major contributor to the ability of exchangeable forms of organic matter to retain heavy metals. Zeng et al. (2011) found that $\mathrm{Cr}$ content in soil and $\mathrm{Cr}$ content in rice tissue were negatively correlated with soil $\mathrm{pH}$ value, but positively correlated with organic matter content. Vega et al. (2006) found that the main soil components affecting the adsorption of one or more heavy metals were organic matter, Fe oxide, sidrite and chlorite content, and CEC. In order to probe into the heavy metal pollution of the soil of the Luona River deposit in Tibet, and the surrounding sediment, Qiao et al. (2020) conducted a study and found that $\mathrm{Cr}$ pollution in the soil mainly comes from river water and sediment polluted by heavy metals.

The present study focuses on the migration of heavy metal $\mathrm{Cr}$ in the sediment of Xinlicheng Reservoir, and the soil at the entrance of the reservoir, Changchun city, Jilin Province, China, and identifies the value of soil $\mathrm{pH}$ and organic matter content as influencing factors so that scientific basis is provided for the future restoration of heavy metal contaminated soil around lakes and reservoirs.

\section{Materials and methods}

\section{Samples for test}

The basin of Xinlicheng Reservoir is slightly rectangular in shape with an average width of $20.7 \mathrm{~km}$. Chromium pollution sources in the water of Xinlicheng Reservoir mainly come from sewage discharge from surrounding factories and $\mathrm{Cr}$ migration 
caused by rainfall. The soil samples were collected from the river inlet, and the surface layer of 0-20 cm soil was collected by quartering method. The soil type was black soil, the land is agricultural cultivated land, the crop is maize, and NPK compound fertilizer is applied. The sediment is collected at surface layer $(0-10 \mathrm{~cm})$ by grab dredger, that is, sampling points are equidistant from the upstream of the reservoir $(5 \mathrm{~km}, 10 \mathrm{~km}, 15 \mathrm{~km}$ away from the reservoir), and the sampling point is $2 \mathrm{~m}$ away from the shore, repeated 3 times for each collection. After the samples collected at the three sampling points were mixed and naturally air-dried indoors, the impurities such as animal and plant residues and rocks were removed, and then the samples were ground through a 10 and 100-mesh sieve for storage. The basic physical and chemical properties of the tested soil samples are shown in Table 1.

Table 1. Physicochemical properties of test soil

\begin{tabular}{|c|c|c|c|c|c|c|c|c|c|}
\hline \multirow[b]{2}{*}{ Sample } & \multirow{2}{*}{$\begin{array}{c}\text { Unit } \\
\text { weight } \\
/\left(\mathrm{g} \cdot \mathbf{m}^{-3}\right)\end{array}$} & \multirow{2}{*}{$\begin{array}{c}\mathrm{OM} / \\
(\mathrm{g} / \mathrm{kg})\end{array}$} & \multirow{2}{*}{$\begin{array}{l}\mathbf{T}_{\mathrm{N}} \\
/ \%\end{array}$} & \multirow{2}{*}{$\begin{array}{r}\mathbf{T} \mathbf{P} \\
/ \%\end{array}$} & \multirow{2}{*}{$\underset{/ \mathbf{m g} \cdot \mathbf{k g}^{-1}}{\mathbf{C r}}$} & \multicolumn{4}{|c|}{ Mechanical composition\% } \\
\hline & & & & & & Sand & $\begin{array}{c}\text { Coarse } \\
\text { silt }\end{array}$ & Fine silt & Clay \\
\hline Sediment & 1.79 & 41.23 & 0.15 & 0.12 & 33.73 & 10.48 & 33.97 & 24.12 & 31.43 \\
\hline Black soil & 1.65 & 34.65 & 0.12 & 0.09 & 26.55 & 4.84 & 51.43 & 22.96 & 20.77 \\
\hline
\end{tabular}

\section{Test design}

\section{Adsorption kinetics}

Adsorption kinetics test was used to evaluate the equilibrium time of subsequent adsorption isotherm tests. In the adsorption kinetics test, soil and water ratio 20:1 was used in $50 \mathrm{ml}$ polyethylene centrifuge tube, and $1.00 \mathrm{~g}$ soil sample and $20 \mathrm{ml} \mathrm{Cr}$ solution with a concentration of $200 \mathrm{mg} \cdot \mathrm{L}^{-1}$ were added, respectively. They oscillate for $1,5,10,20,30,60,120,240,360,480,720,1440 \mathrm{~min}$ at the temperature of $25^{\circ} \mathrm{C}$. After centrifugation at $4000 \mathrm{r} \cdot \mathrm{min}^{-1}$ for $10 \mathrm{~min}$, the concentration of $\mathrm{Cr}$ in the supernatant was determined by filtration with 0.45 um microporous membrane (Dali-Youcef et al., 2006).

\section{Adsorption isotherm}

The $1.00 \mathrm{~g}$ samples of sediment and soil were added into a $50 \mathrm{~mL}$ polyethylene centrifuge tube to study the adsorption isotherm of $\mathrm{Cr}$ on sediment and soil. The influence of univariate time on the adsorption of $\mathrm{Cr}$ on sediment and black soil was studied when different initial concentrations of $\mathrm{Cr}$ were 50,100, 200,300, 400 and $500 \mathrm{mg} \cdot \mathrm{L}^{-1}$, respectively. Adsorption kinetics on the basis of constant temperature oscillation at $25^{\circ} \mathrm{C}$ to obvious equilibrium, the test tube with $\mathrm{Cr}$ solution added as blank, centrifugation, filtration, determination and other steps are the same as Adsorption kinetics (Arias et al., 2006).

\section{Influence of temperature on adsorption isotherm}

The adsorption of $\mathrm{Cr}$ onto sediment and soil at $15^{\circ} \mathrm{C}, 25^{\circ} \mathrm{C}$ and $35^{\circ} \mathrm{C}$ was studied by referring to the batch adsorption test. The influence of single variable temperature on the adsorption of $\mathrm{Cr}$ onto sediment and black soil at different initial concentrations of 50, 100, 200, 300, 400 and $500 \mathrm{mg} \cdot \mathrm{L}^{-1}$ was determined (Abat et al., 2012). 


\section{Influence of $\mathrm{pH}$ on adsorption isotherm}

The solutions of $0.1 \mathrm{~mol} \cdot \mathrm{L}^{-1} \mathrm{HCl}$ and $1.0 \mathrm{~mol} \cdot \mathrm{L}^{-1} \mathrm{NaOH}$ were used to adjust the $\mathrm{pH}$ values of different $\mathrm{Cr}$ solutions to 3, 5, 7, 9 and 11. According to Adsorption isotherm method, adsorption isothermal determination was conducted at $25^{\circ} \mathrm{C}$ to study the effect of $\mathrm{pH}$ change of a single variable on the adsorption of $\mathrm{Cr}$ on sediment and black soil.

\section{Influence of organic matter content on adsorption isotherm}

The organic matter in sediment and soil was removed by $\mathrm{H}_{2} \mathrm{O}_{2}$ digestion. The bottom mud and soil samples were weighed after air drying, and soaked with $6 \% \mathrm{H}_{2} \mathrm{O}_{2}$ for $24 \mathrm{~h}$, and after that $30 \% \mathrm{H}_{2} \mathrm{O}_{2} 100 \mathrm{ml}$ was added for several times. Repeated treatment was made till no bubbles emerged from the samples. The residual $\mathrm{H}_{2} \mathrm{O}_{2}$ was removed by heating method and finally washed with deionized water.

Organic matter samples were taken respectively (with non-removed organic matter samples as the control), and the adsorption isotherm was determined at $25^{\circ} \mathrm{C}$ according to Adsorption isotherm method, to study the influence of changes in single variable organic matter on sediment and soil $\mathrm{Cr}$ adsorption.

\section{Analysis of adsorption data}

\section{Adsorption kinetic model}

Elovich equation:

$$
q_{t}=a+b n_{t}
$$

Parabolic diffusion equation:

$$
S / S_{\max }=a+b t^{1 / 2}
$$

where, $\mathrm{a}$ is the adsorption constant related to the maximum adsorption capacity, and $\mathrm{b}$ is the adsorption rate coefficient, which can be interpreted as how fast the reaction rate decreases. The Elovich equation is used to explain the adsorption process of heterogeneous diffusion because the activation energy varies greatly during the reaction.

Isothermal fitting equation (Fan et al., 2012):

The Freundlich equation:

$$
q_{e}=K_{F} C_{t}^{1 / n}(\text { Nonlinear form })
$$

D-R equation:

$$
\ln q_{e}=\ln q_{m}-k \varepsilon^{2}
$$

where, $\mathrm{q}_{\mathrm{e}}$ is the adsorbed amount of $\mathrm{Cr}\left(\mathrm{mg} \cdot \mathrm{g}^{-1}\right)$; $\mathrm{q}_{\mathrm{m}}$ is the maximum adsorption capacity, $\mathrm{k}$ is the constant related to the adsorption energy, $\varepsilon$ is the adsorption potential of Polanyi, $\mathrm{K}_{\mathrm{F}}$ is the constant, $\mathrm{n}$ is the affinity value of the constant. All these formula 
symbols respectively represent the maximum adsorption capacity of $\mathrm{Cr}$ and the adsorption capacity.

Thermodynamic parameter equation (Chen et al., 2011):

$$
\begin{aligned}
& \Delta G=-R T \ln K_{F} \\
& \Delta G=\Delta H-T \Delta S
\end{aligned}
$$

Type: $\Delta \mathrm{G}$ for the change of Gibbs free energy $\left(\mathrm{kJ} \cdot \mathrm{mol}^{-1}\right), \Delta \mathrm{G}<0$ indicates that reactions can occur spontaneously, $\Delta \mathrm{G}>0$ reaction can't occur spontaneously; $\Delta \mathrm{H}$ is the standard enthalpy change $\left(\mathrm{kJ} \cdot \mathrm{mol}^{-1}\right), \Delta \mathrm{H}<0$ indicates the reaction is exothermic, while $\Delta \mathrm{H}>0$ indicates the reaction is endothermic; $\mathrm{T}(\mathrm{K})$ is the absolute temperature; $\mathrm{R}$ is the ideal gas constant $=8.314 \times 10^{-3} \mathrm{KJ} \cdot \mathrm{mol}^{-1} \cdot \mathrm{K}^{-1} ; \Delta \mathrm{S}$ is the standard entropy change $\left(\mathrm{KJ} \cdot \mathrm{mol}^{-1} \cdot \mathrm{K}^{-1}\right), \Delta \mathrm{S}<0$ means chaotic degree is reduced, $\Delta \mathrm{S}>0$ indicates confusion degree is increased; $K_{F}$ stands for thermodynamic equilibrium constant. When the $1 / T$ and $\operatorname{lnK}$ are used to draw horizontal and vertical curves, $\Delta \mathrm{H}$ and $\Delta \mathrm{S}$ can be obtained according to the slope and intercept, respectively.

All tests were performed in triplicate.

\section{Results and discussion}

\section{Adsorption kinetics of $\mathrm{Cr}$}

Figure 1 depicts the adsorption of heavy metal $\mathrm{Cr}$ in sediment and soil at $25^{\circ} \mathrm{C}$ and shows that the whole adsorption process of metal $\mathrm{Cr}$ in sediment and soils consist of two stages, the rapid adsorption stage and the slow equilibrium adsorption stage. Within 0-120 min, with the increase of adsorption time, the adsorption amount of $\mathrm{Cr}$ by sediment and black soil increases significantly, and the concentration of $\mathrm{Cr}$ in solution decreases rapidly. However, within 120-1440 min can be categorized into the slow equilibrium stage. At this stage, the change of $\mathrm{Cr}$ concentration in solution gradually tends to be in equilibrium. Kinetic test demonstrates that the adsorption equilibrium time of $\mathrm{Cr}$ in sediment and soil is $1440 \mathrm{~min}$, and the maximum adsorption amount of $\mathrm{Cr}$ in sediment and black soil is $1665.02 \mathrm{mg} \cdot \mathrm{kg}^{-1}$ and $1079.04 \mathrm{mg} \cdot \mathrm{kg}^{-1}$, respectively. In the rapid adsorption stage, the adsorption capacity of $\mathrm{Cr}$ by sediment and black soil reaches $79.21 \%$ and $78.97 \%$ of the total adsorption capacity, respectively. With the passage of adsorption time, the heavy metal $\mathrm{Cr}$ in the solution is in full contact with the sediment and the black soil, and gradually occupies the adsorption site in the adsorbent, so the adsorption capacity of the sediment and the black soil gradually increases (Tokunaga et al., 2001; Li et al., 2013). The higher adsorption capacity of $\mathrm{Cr}$ in sediment may be due to the high content of organic matter in sediment, which can provide more adsorption points for $\mathrm{Cr}$ (Liu and Dai, 2015). In the process of Cr adsorption by sediment and soil, some components in the sediment and soil may form complex with $\mathrm{Cr}$, transfer the $\mathrm{Cr}$ adsorbed on the surface of sediment and soil to the interior of particles, and lead to more $\mathrm{Cr}$ forming precipitation on the surface of sediment and black soil. When the adsorption time reaches $2 \mathrm{~h}$, the adsorption amount of $\mathrm{Cr}$ in the bottom mud and black soil reaches about $80 \%$ of the total adsorption amount, and the equilibrium adsorption state can be 
reached at $24 \mathrm{~h}$. Thus, it can be seen that the bottom mud and black soil have a strong accumulation capacity for heavy metal $\mathrm{Cr}$.

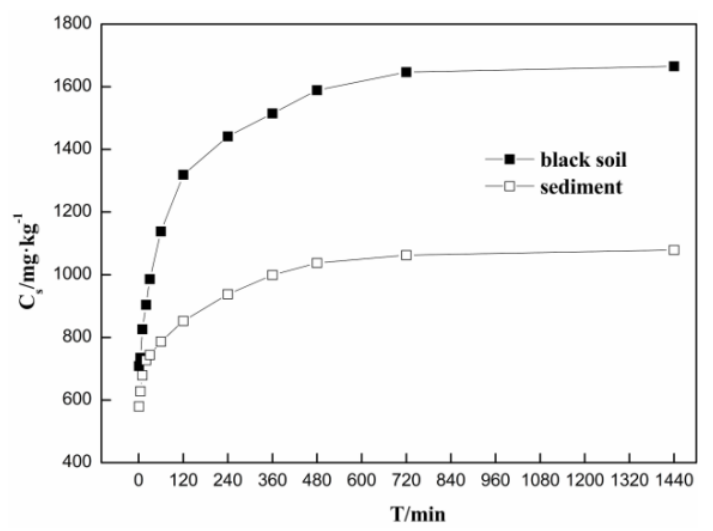

Figure 1. The adsorption kinetics curves of $\mathrm{Cr}$ in black soil and sediment

Elovich equation and parabolic diffusion equation were used to fit $\mathrm{Cr}$ adsorption kinetic data, so as to understand $\mathrm{Cr}$ adsorption mechanism in sediment and soil. Generally, the better the model is, the greater the $\mathrm{R}^{2}$ value will be. Table 2 shows the fitting parameters of the equation. It can be seen that the adsorption correlation coefficient $\mathrm{R}^{2}$ of Elovich equation for $\mathrm{Cr}$ in sediment and soil was 0.9444 and 0.9569 , respectively, which being greater than that of the parabolic diffusion equation $\left(\mathrm{R}^{2} 0.8105\right.$ and 0.8485 , respectively), indicating that Elovich equation was more suitable for descriptions the $\mathrm{Cr}$ adsorption kinetics characteristics in sediment and soil. The higher the constant a value in Elovich equation, the higher the adsorption rate, and therefore the metal $\mathrm{Cr}$ is more likely to accumulate in the sediment. Elovich equation is an empirical equation, which is used to describe the adsorption behavior of pollutants on the non-uniform solid adsorption surface and is suitable for the process in which the activation energy changes greatly during the reaction process. The adsorption process involves not only particle diffusion but also multiple forces.

Table 2. Parameters of the kinetics adsorption models for Cr in sediment and black soil

\begin{tabular}{c|c|c|c|c|c|c|c}
\hline \multirow{2}{*}{ Soil type } & \multicolumn{3}{|c|}{ Elovich equation } & \multicolumn{3}{c}{ Parabolic diffusion equation } \\
\cline { 2 - 8 } & $\mathbf{a}$ & $\mathbf{b}$ & $\mathbf{R}^{\mathbf{2}}$ & $\mathbf{a}$ & $\mathbf{b}$ & $\mathbf{S}$ & $\mathbf{R}^{\mathbf{2}}$ \\
\hline Sediment & 526.6285 & 161.1724 & 0.9444 & 30.6494 & 1.0879 & 26.9135 & 0.8105 \\
Black soil & 512.2667 & 78.3782 & 0.9569 & 122.2293 & 2.6892 & 5.3592 & 0.8485 \\
\hline
\end{tabular}

Note: R stands for correlation coefficient; $\mathrm{p}<0.01$ indicates significant correlation

\section{Adsorption isotherm}

The isotherm of heavy metal $\mathrm{Cr}$ in sediment and soil at $25^{\circ} \mathrm{C}$ are introduced in Figure 2 and Figure 3. From the Figures, with the increase of $\mathrm{Cr}$ concentration, the adsorption isotherms of $\mathrm{Cr}$ on the sediment and soil are on a gradual upward trend of slope, but the adsorption does not reach the saturation state. Within the test concentration range, when the initial concentration of $\mathrm{Cr}$ is $500 \mathrm{mg} \cdot \mathrm{kg}^{-1}$, the equilibrium adsorption capacity of sediment and soil to $\mathrm{Cr}$ reaches 8623.43 and $8396.40 \mathrm{mg} \cdot \mathrm{kg}^{-1}$, respectively. The 
adsorption trend of $\mathrm{Cr}$ by different adsorbents (sediment and black soil) is roughly the same, but the adsorption amount is significantly different.

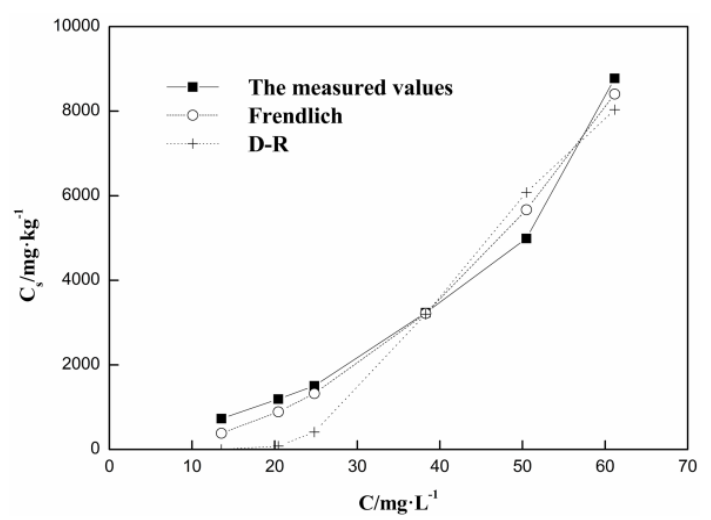

Figure 2. Adsorption isotherms of Cr in sediment

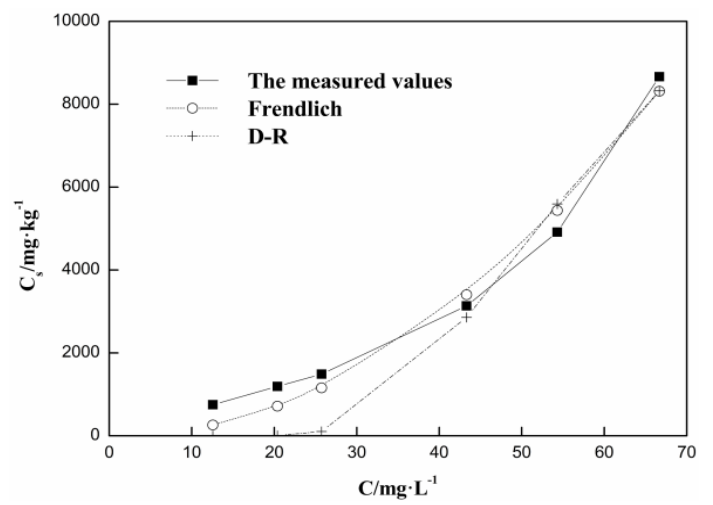

Figure 3. Adsorption isotherms of Cr in black soil

The isothermal adsorption curve of $\mathrm{Cr}$ by sediment and soil shows an "S" type. Through the adsorption isotherm data fitting, it is found that the Freundlich (Alemayehu et al., 2011) and D-R model has better data fitting effect than Langmuir model, which can explain the adsorption mechanism of $\mathrm{Cr}$ on sediment and soil more reasonably. Table 3 shows the adsorption parameters of Freundlich and D-R. In the Freundlich model fitting, chromium adsorption coefficient $\mathrm{R}(0.9882$ and 0.9834$)$ in sediment and soil is higher than that of D-R model (0.9663 and 0.9675). This is mainly because when the concentration of $\mathrm{Cr}$ is less than $500 \mathrm{mg} \mathrm{L}^{-1}$, the adsorption of $\mathrm{Cr}$ by sediment and soil does not reach saturation state. The Freundlich equation's adsorption constant $\mathrm{K}_{\mathrm{f}}$ represents the adsorption capacity of the adsorbent. $\mathrm{K}_{\mathrm{f}}$ sediment is 0.4439 larger than $\mathrm{K}_{\mathrm{f}}$ soil, indicating that the sediment is more likely to absorb the metal $\mathrm{Cr}$ than the soil.

Table 3. Parameters of the kinetics adsorption models for Cr in sediment and black soil

\begin{tabular}{c|c|c|c|c|c|c|c}
\hline \multirow{2}{*}{ Soil type } & \multicolumn{3}{|c|}{ Freundlich model } & \multicolumn{4}{c}{ D-R model } \\
\cline { 2 - 8 } & $\mathbf{K}_{\mathbf{f}}$ & $\mathbf{n}$ & $\mathbf{r}$ & $\mathbf{q m}$ & $\mathbf{b}$ & $\mathbf{k}$ & $\mathbf{r}$ \\
\hline Sediment & 1.8293 & 0.4882 & $0.9882 * *$ & 14677.4102 & 0.1789 & 372.7705 & $0.9663 * *$ \\
Black soil & 1.3854 & 0.4835 & $0.9834 * *$ & 18359.7303 & 0.0346 & 581.1108 & $0.9675 * *$ \\
\hline
\end{tabular}

Note: $\mathrm{n}=12, \mathrm{r} 0.05=0.0 .576, \mathrm{r} 0.01=0.708$, **Represents significance level $(\mathrm{p}<0.01)$ 


\section{Adsorption thermodynamics}

Temperature is not only an important environmental factor affecting adsorption but also an important condition affecting adsorption membrane properties. The thermodynamic curves of $\mathrm{Cr}$ adsorption in sediment and soil are depicted in Figure 4 and Figure 5. It can be seen from the Figures that the adsorption of $\mathrm{Cr}$ in sediment and soil are $8623.40,8776.82,8911.64 \mathrm{mg} \cdot \mathrm{kg}^{-1}$ and $8396.40,8666.46,8846.86 \mathrm{mg} \cdot \mathrm{kg}^{-1}$ under the temperatures of $15^{\circ} \mathrm{C}, 25^{\circ} \mathrm{C}$ and $35^{\circ} \mathrm{C}$, respectively. With temperature increasing, the adsorption capacity of $\mathrm{Cr}$ in sediment and soil gradually enhances. It indicates that the higher the temperature is, the more favorable it is for $\mathrm{Cr}$ adsorbed on the bottom mud and soil surface to diffuse into the particle interior, and conducive to the transformation from thermodynamic unstable compound state to stable compound state.

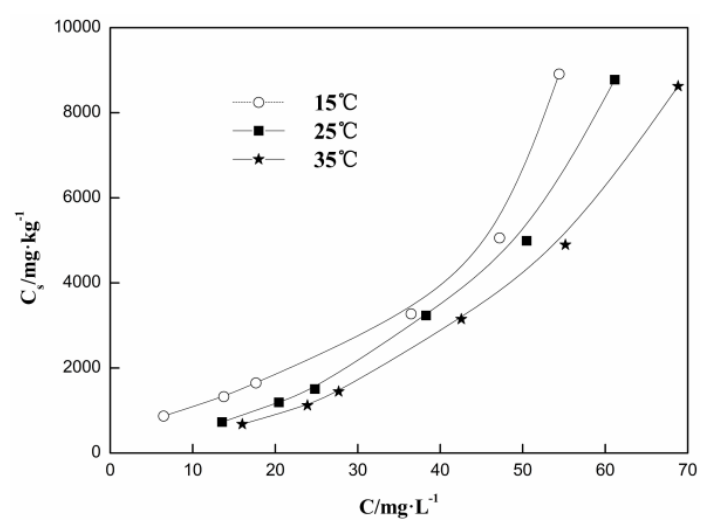

Figure 4. Thermodynamic curves of Cr in sediment

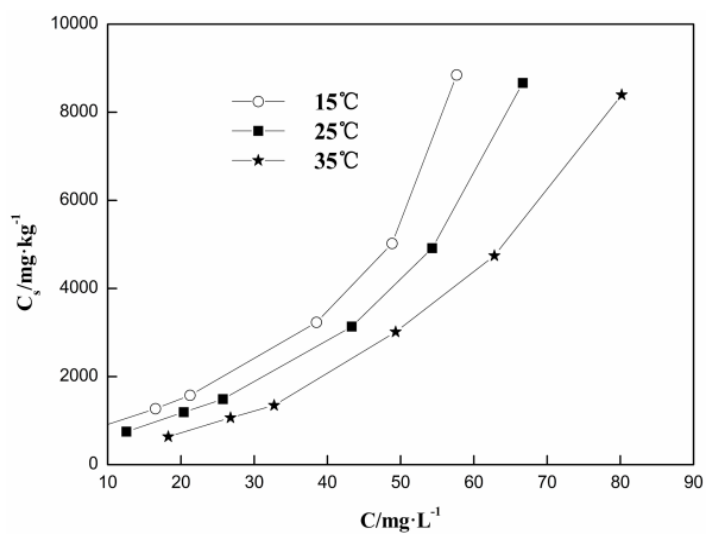

Figure 5. Thermodynamic curves of Cr black soils

Table 4 and Table 5 show the adsorption thermodynamic parameters of $\mathrm{Cr}$ in sediment and soil. It can be seen that the Freundlich model has the best fitting effect, and the $Q_{m}$ value increases with the increase of temperature, which further demonstrates that high temperature is conducive to the adsorption of $\mathrm{Cr}$ in sediment and soil. It can be observed from Table 5 that within the test temperature range $\left(15,25\right.$ and $\left.35^{\circ} \mathrm{C}\right), \Delta \mathrm{G}$ are less than zero; $\Delta \mathrm{H}>0$ shows that sediment and soil adsorption of $\mathrm{Cr}$ process is a 
spontaneous endothermic process, and high temperature is beneficial to spontaneous adsorption. The adsorption of heavy metals by adsorbents experiences an endothermic process, and the experimental results are consistent with the trend of (Singh et al., 2017). $\Delta \mathrm{G}$ and $\Delta \mathrm{H}$ show that seasonal differences exist in sediment, soil buffer capacity $\mathrm{Cr}$, liquidity and activity of (Lyubchik et al., 2004; Alothman et al., 2013).

Table 4. Adsorption simulation equation parameters for different temperatures

\begin{tabular}{c|c|c|c|c|c|c|c}
\hline \multirow{2}{*}{ Sample type } & Temperature & \multicolumn{3}{|c|}{ Freundlich equation } & \multicolumn{3}{c}{ D-R equation } \\
\cline { 3 - 8 } & $\left({ }^{\circ} \mathbf{C}\right)$ & $\mathbf{K}_{\mathbf{f}}$ & $\mathbf{n}$ & $\mathbf{R}^{\mathbf{2}}$ & $\mathbf{q m}$ & $\mathbf{k}$ & $\mathbf{R}^{\mathbf{2}}$ \\
\hline \multirow{3}{*}{ Sediment } & 15 & 1.430 & 0.488 & 0.9902 & 14279.30 & 452.5590 & 0.8990 \\
& 25 & 1.829 & 0.488 & 0.9776 & 14677.41 & 372.7706 & 0.8753 \\
& 35 & 3.313 & 0.513 & 0.9008 & 21766.84 & 470.4402 & 0.8118 \\
\hline \multirow{3}{*}{ Black soil } & 15 & 1.015 & 0.487 & 0.9948 & 14445.38 & 632.5860 & 0.9161 \\
& 25 & 1.385 & 0.483 & 0.9364 & 18359.73 & 581.1089 & 0.8757 \\
& 35 & 1.756 & 0.479 & 0.9382 & 21138.22 & 506.8181 & 0.8435 \\
\hline
\end{tabular}

Table 5. Adsorption thermodynamic parameters of $\mathrm{Cr}$ in sediment and soil

\begin{tabular}{c|c|c|c|c|c}
\hline \multirow{2}{*}{ Soil type } & \multicolumn{3}{|c|}{$\boldsymbol{\Delta G}$} & \multirow{2}{*}{$\boldsymbol{\Delta} \mathbf{H}$} & \multirow{2}{*}{$\mathbf{S}$} \\
\cline { 2 - 5 } & $\mathbf{1 5}^{\circ} \mathbf{C}$ & $\mathbf{2 5}^{\circ} \mathbf{C}$ & $\mathbf{3 5}^{\circ} \mathbf{C}$ & 30.8503 & 0.1105 \\
Sediment & -0.8507 & -1.9506 & -3.0504 & 30.05 & 0.0708 \\
\hline Black soil & -0.0702 & -0.6309 & -1.3306 & 20.2406 & \\
\hline
\end{tabular}

\section{Effect of $\mathrm{pH}$ on Cr adsorption}

A variety of factors can affect the adsorption of metal $\mathrm{Cr}$ by the adsorbent. Figure 6 shows the effect of different $\mathrm{pH}$ values on the adsorption of metal $\mathrm{Cr}$. It can be seen that with the increase of $\mathrm{pH}$ value, the adsorption capacity of sediment and soil to $\mathrm{Cr}$ first increases and then decreases. When the $\mathrm{pH}$ value of the experimental environment was 3 , chromium has the lowest adsorption capacity in sediment and soil, which was $3090.62 \mathrm{mg} \cdot \mathrm{kg}^{-1}$ and $2256.62 \mathrm{mg} \cdot \mathrm{kg}^{-1}$, respectively. When $\mathrm{pH}$ was 7 , it reaches the turning point of adsorption, and the maximum adsorption capacity was 3140.02 and $2406.84 \mathrm{mg} \cdot \mathrm{kg}^{-1}$, respectively.

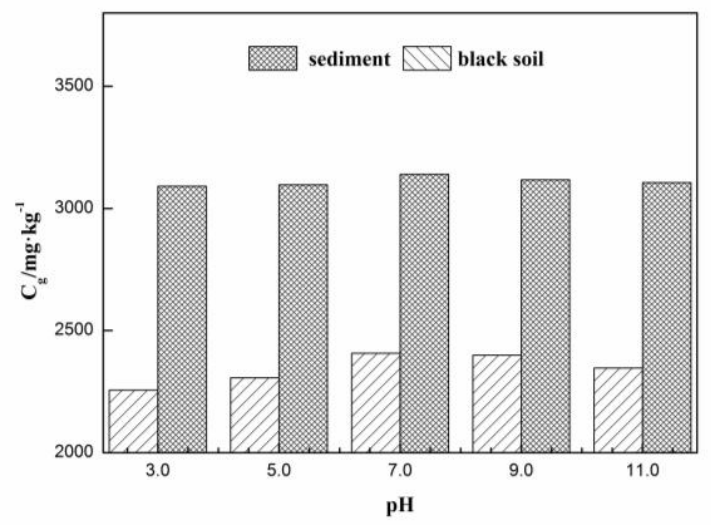

Figure 6. Effect of pH on Cr adsorption in sediment and black soil 
When the $\mathrm{pH}$ value was within the range of 7-9, the adsorption effect of heavy metal $\mathrm{Cr}$ reaches the maximum level in sediment and soils, and the adsorption capacity of $\mathrm{Cr}$ was stronger in sediment. When $\mathrm{pH}$ was 11 , the content of $\mathrm{OH}^{-}$in the solution increases, and the competitive adsorption from $\mathrm{H}^{+}$decreases. At this time, the activity of $\mathrm{Cr}$ decreases, thus reducing the migration ability of $\mathrm{Cr}$ in soil and sediment. The adsorption amount of $\mathrm{Cr}$ in sediment and soil was the smallest when the $\mathrm{pH}$ was 3, and the adsorption amount was the largest when the $\mathrm{pH}$ was 7 . Within the $\mathrm{pH}$ range of the test, higher and lower $\mathrm{pH}$ values were not conducive to the adsorption of $\mathrm{Cr}$ by sediment and soil. With the increase of $\mathrm{pH}$, the adsorption capacity of $\mathrm{Cr}$ by soil and sediment first increased and then decreased. The adsorption amount of $\mathrm{Cr}$ in sediment and soil was the

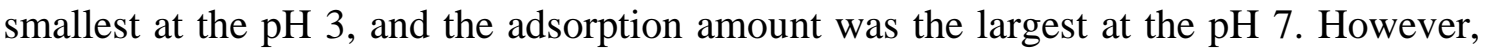
the difference between adsorption of $\mathrm{Cr}$ under different $\mathrm{pH}$ in the sediment was not significant $(\mathrm{p}>0.05)$, and the adsorption of $\mathrm{Cr}$ under different $\mathrm{pH}$ in the soil was significant $(\mathrm{p}<0.05)$. This may be due to the higher content of organic matter in the sediment, and higher organic matter makes the sediment have a higher adsorption capacity of $\mathrm{Cr}$, so the impact of organic matter content was greater than the $\mathrm{pH}$ value.

The reason for this phenomenon was assumed to be that when $\mathrm{pH}$ was 3 , the solution contains a large number of $\mathrm{H}^{+}$, and the presence of $\mathrm{H}^{+}$produces competitive adsorption with $\mathrm{Cr}$. The $\mathrm{pH}$ changes the existing form of $\mathrm{Cr}$ in sediment and soil. The lower the $\mathrm{pH}$ is, the greater the potential difference of the system will be, thus making it easier for some $\mathrm{Cr}(\mathrm{VI})$ to be converted into $\mathrm{Cr}(\mathrm{III})$. $\mathrm{Cr}(\mathrm{III})$ produces precipitation benefit, reducing the equilibrium concentration of $\mathrm{Cr}(\mathrm{VI})$ in solution (Chen et al., 2015). The $\mathrm{pH}$ affects $\mathrm{H}^{+}$concentration in sediment and soil. The lower the $\mathrm{pH}$, the higher the $\mathrm{H}^{+}$ concentration, the dissociation of hydroxyl group $(-\mathrm{OH})$ on the surface of soil colloidal particles will be affected, and the potential balance of the colloidal group will be destroyed (Liu et al., 2012). With the increase of $\mathrm{pH}$, the content of $\mathrm{H}^{+}$in the solution decreases gradually, competitive adsorption decreases, and $\mathrm{OH}^{-}$increases. The content of calcium carbonate and hydroxyl $(-\mathrm{OH})$ in the colloidal core in the soil was high, which strengthens the adsorption and fixation of $\mathrm{Cr}$ by carbonate and oxide in the soil (Zhang et al., 2017). When $\mathrm{pH}$ value continues to rise, the increase of $\mathrm{OH}^{-}$concentration will reduce the proton adsorption sites on the surface of adsorbent, enhance the electro negativity of sediment and soil surface, and weaken the adsorption capacity of anionic groups such as $\mathrm{HCrO}_{4}^{-}, \mathrm{CrO}_{4}{ }^{2-}$ and $\mathrm{Cr}_{2} \mathrm{O}_{7}{ }^{2-}$, resulting in the decline of $\mathrm{Cr}$ adsorption capacity (Wang et al., 2013).

\section{Effects of organic matter on Cr adsorption}

As one of the most active solid components in soil chemistry, soil organic matter has a strong adsorption effect on pollutants, thus affecting their migration behavior. When the content of organic matter was high, these organic matter can be complexed with heavy metal ions, thus changing the adsorption property of soil and sediment. The cation exchange capacity in soil and sediment was restricted by oxygen-containing functional groups in humus. Therefore, the humic acid in organic matter can change the cation exchange capacity and thus affect the adsorption capacity of soil and sediment to Cr. Figure 7 and Figure 8 show the changes of $\mathrm{Cr}$ adsorption before and after removal of organic matter from sediment and soil. It can be seen that before and after the removal of organic matter, when the concentration of $\mathrm{Cr}$ added in the solution was at most $500 \mathrm{mg} \cdot \mathrm{L}^{-1}$, the $\mathrm{Cr}$ adsorption capacity of sediment reached 8776.82 and $5836.58 \mathrm{mg} \cdot \mathrm{kg}^{-1}$, and the $\mathrm{Cr}$ adsorption capacity of soil was 8646.46 and 
$5826.52 \mathrm{mg} \cdot \mathrm{kg}^{-1}$, respectively, moreover, the difference of adsorption amount for $\mathrm{Cr}$ between before and after the removal of organic matter in sediment and soil was significant $(\mathrm{P}<0.05)$. According to the formula of contribution rate $=(\mathrm{Q}-\mathrm{Q}$ removal $) / \mathrm{Q}$ removal, the contribution rate of organic matter in sediment and soil to $\mathrm{Cr}$ was $50.38 \%$ and $48.40 \%$, respectively. This is related to the organic matter content of the sediment and soil. Organic matter provides large amounts of pollutants adsorption points, and has a strong surface adsorption capacity. The organic matter can reduce hexavalent $\mathrm{Cr}$ to trivalent $\mathrm{Cr}$ in sediment and soil, and make it into a fixed precipitation state and the organic combination state and lose activity (Agrafioti et al., 2014).

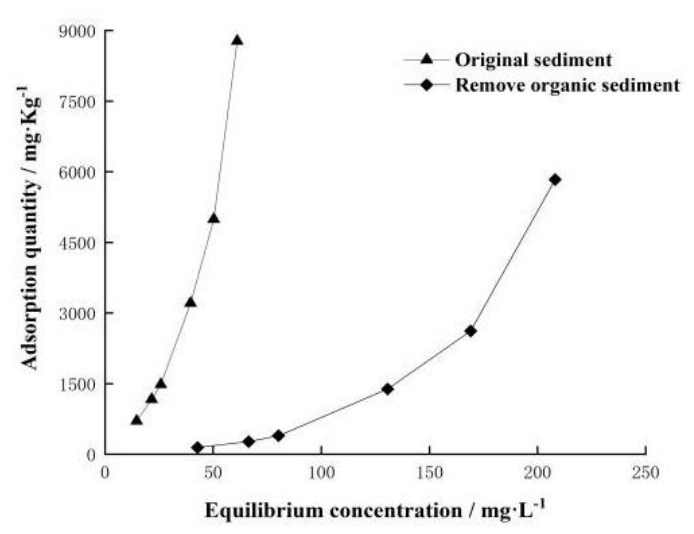

Figure 7. Adsorption isotherm of Cr onto sediment before and after removal of organics

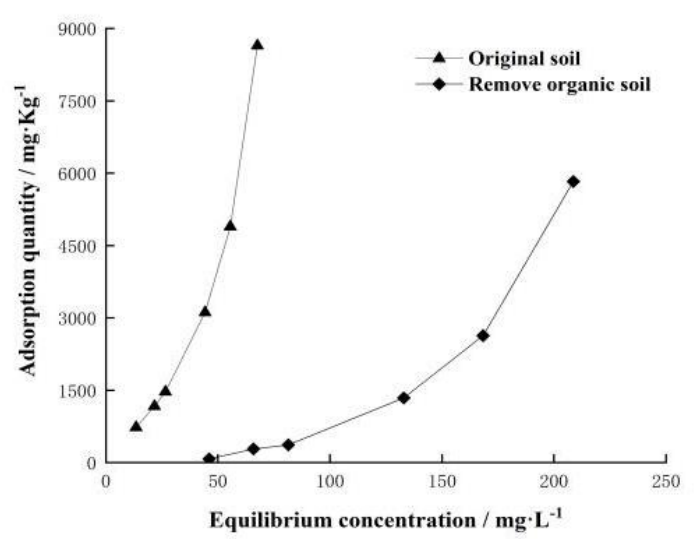

Figure 8. Adsorption isotherm of Cr onto soil before and after removal of organics

\section{Conclusion}

(1) Compared with the soil, the lake sediment had a strong adsorption capacity for $\mathrm{Cr}$ under the same condition, and the maximum adsorption amount of $\mathrm{Cr}$ in sediment and soil was $1,665.02 \mathrm{mg} \cdot \mathrm{kg}^{-1}$ and $1079.04 \mathrm{mg} \cdot \mathrm{kg}^{-1}$, respectively. The isothermal adsorption curve of $\mathrm{Cr}$ in sediment and soil showed an "S" type, and the Freundlich equation was better to describe the thermodynamic characteristics of $\mathrm{Cr}$ adsorption.

(2) Within the temperature range designed in the experiment, the thermodynamic parameters $\mathrm{G}<0, \Delta \mathrm{H}>0$, indicates that sediment and soil adsorption of $\mathrm{Cr}$ process is 
spontaneous and endothermic, and high temperature is beneficial to the spontaneity of the adsorption.

(3) In the test $\mathrm{pH}$ range, higher and lower $\mathrm{pH}$ values are not conducive to the adsorption of $\mathrm{Cr}$ by sediment and soil. With the increase of $\mathrm{pH}$ value, the adsorption capacity of soil and sediment to $\mathrm{Cr}$ first increased and then decreased. The adsorption capacity of $\mathrm{Cr}$ by sediment and soil is minimum at $\mathrm{pH} 3$ and maximum at $\mathrm{pH} 7$. Therefore, in acidic and alkaline environment, it is not conducive to the fixation of $\mathrm{Cr}$ in soil and sediment, which increases the environmental risk of $\mathrm{Cr}$.

(4) The contribution rate of organic matter in sediment and soil to $\mathrm{Cr}$ was $50.38 \%$ and $48.40 \%$, respectively. After the organic matter is removed, the adsorption capacity was significantly reduced, the activity of $\mathrm{Cr}$ increases and resulted in the increase of the environmental risk of $\mathrm{Cr}$.

This article studied the adsorption characteristics of $\mathrm{Cr}$ in sediment and soil, and effects of the value of $\mathrm{pH}$ and content of organic matter on the absorption capacity of $\mathrm{Cr}$, in order to seek effective control measures of the $\mathrm{Cr}$ environmental risk in soil and sediment through adjusting the environmental conditions such as temperature, the content of organic matter and $\mathrm{pH}$ and so on.

Acknowledgements. The research was funded by the National Natural Science Foundation of China (Grant No.: 31672051), the Development Plan of Jilin Provincial Department of Science and Technology (Grant No.: 20200402013NC), Project of Natural Science Foundation of Jilin Province (20200201217JC) and Jilin Provincial Department of Education (Grant No.: JJKH20200337KJ).

Conflicts of Interests. The authors declare no conflict of interests.

\section{REFERENCES}

[1] Abat, M., McLaughlin, M. J., Kirby, J. K., Stacey, S. P. (2012): Adsorption and desorption of copper and zinc in tropical peat soils of Sarawak, Malaysia. - Geoderma 175-176: 58-63.

[2] Agrafioti, E., Kalderis, D., Diamadopoulos, E. (2014): Arsenic and chromium removal from water using biochars derived from rice husk, organic solid wastes and sewage sludge. - Journal of Environmental Management 133: 309-314.

[3] Alemayehu, E., Thiele-Bruhn, S., Lennartz, B. (2011): Adsorption behaviour of Cr(VI) onto macro and micro-vesicular volcanic rocks from water. - Separation \& Purification Technology 78(1): 55-61.

[4] Alothman, Z., Naushad, M., Ali, R. (2013): Kinetic, equilibrium isotherm and thermodynamic studies Drinčić Aof Cr (VI) adsorption onto low-cost adsorbent developed from peanut shell activated with phosphoric acid. - Environmental Science \& Pollution Research 20(5): 3351-3365.

[5] Arias, M., Pérez-Novo, C., López, E., Soto, B. (2006): Competitive adsorption and desorption of copper and zinc in acid soils. - Geoderma 133(3-4): 151-159.

[6] Chen, X., Chen, G., Chen, L., Chen, Y., Lehmann, J., McBride, M. B., Hay, A. G. (2011): Adsorption of copper and zinc by biochars produced from pyrolysis of hardwood and corn straw in aqueous solution. - Bioresource Technology 102(19): 8877-8884.

[7] Chen, S. Y., Wang, C. D., Li, S. X. (2015): Different pH on the adsorption of Cr (VI) in purple soil. - Environmental engineering 857-860.

[8] Dali-Youcef, N., Ouddane, B., Derriche, Z. (2006): Adsorption of zinc on natural sediment of Tafna River (Algeria). - Journal of Hazardous Materials 137(3): 1263-1270. 
[9] Dong, D., Zhao, X., Hua, X., Liu, J., Gao, M. (2009): Investigation of the potential mobility of $\mathrm{Pb}, \mathrm{Cd}$ and $\mathrm{Cr}(\mathrm{VI})$ from moderately contaminated farmland soil to groundwater in northeast, China. - Journal of Hazardous Materials 162(2-3): 1261-1268.

[10] Drinčić, A., Zuliani, T., Ščančar, J., Milačič, R. (2018): Determination of hexavalent Cr in river sediments by speciated isotope dilution inductively coupled plasma mass spectrometry. - Science of the Total Environment 637-638: 1286-1294.

[11] Fan, T., Liu, Y., Feng, B., Zeng, G., Yang, C., Zhou, M., Zhou, H., Tan, Z., Wang, X. (2008): Biosorption of Cadmium(II), Zinc(II) and Lead(II) by Penicillium simplicissimum: Isotherms, kinetics and thermodynamics. - Journal of Hazardous Materials 160(2-3): 655-661.

[12] Fonseca, B., Maio, H., Quintelas, C., Teixeira, A., Tavares, T. (2009): Retention of Cr(VI) and $\mathrm{Pb}(\mathrm{II})$ on a loamy sand soil: kinetics, equilibria and breakthrough. - Chemical Engineering Journal 152(1): 212-219.

[13] Jiang, B., Gong, Y. F., Gao, J. N., Sun, T., Liu, Y. J., Oturan, N., Oturan, M. A. (2018): The reduction of $\mathrm{Cr}$ (VI) to $\mathrm{Cr}$ (III) mediated by environmentally relevant carboxylic acids: State-of-the-art and perspectives. - Journal of hazardous materials 365: 205-226.

[14] Li, Y., Liu, W., Chen, F., Zhao, Q. (2013): Adsorption properties of thiol-functionalized bentonite for heavy metals. - Chinese Journal of Environmental Engineering 7(8): 30133018.

[15] Liu, Z. J., Chen, L., Dong, Y., Li, Y. Y., Wang, P. (2012): The ionic strength, pH and concentration of humic acid on $63 \mathrm{Ni}$ ( II ) on gamma Al203 adsorption. - The effect of chemical and nuclear radiation chemistry 34(6): 369-373.

[16] Liu, H., Dai, J. L. (2015): The effect of organic matter and organic acid on the chromium release in sediment. - Advanced Materials Research 1081: 88-92.

[17] Liu, W., Jin, L. D., Xu, J., Liu, J., Li, Y. Y., Zhou, P. P., Wang, C. C., Dahlgren, R. A., Wang, X. D. (2018): Insight into pH Dependent Cr (VI) Removal with Magnetic Fe3S4. - Chemical Engineering Journal 359: 564-571.

[18] Lyubchik, S. I., Lyubchik, A. I., Galushko, O. L., Tikhonova, L. P., Vital, J., Fonseca, I. M., Lyubchik, S. B. (2004): Kinetics and thermodynamics of the $\mathrm{Cr}$ (III) adsorption on the activated carbon from co-mingled wastes. - Colloids \& Surfaces A Physicochemical \& Engineering Aspects 242(1-3): 151-158.

[19] Pan, D. M., Ding, S. L. (2011): Advances in adsorption, migration and accumulation of chromium in soil and plants. - Western leather 33(2): 22-25.

[20] Qiao, D., Wang, G., Li, X., Wang, S., Zhao, Y. (2020): Pollution, sources and environmental risk assessment of heavy metals in the surface amd water, sediments and surface soils around unexploited Rona $\mathrm{Cu}$ deposit, Tibet, China. - Chemosphere 248: 125988. https://doi.org/10.1016/j.chemosphere.2020.125988.

[21] Singh Rathore, A., Kishore Gupta, G., Kapur, M., Kumar Mondal, M. (2017): Study on mass transfer characteristics for $\mathrm{Cr}(\mathrm{VI})$ removal by adsorption onto residual black toner ink. - Environmental Progress \& Sustainable Energy 36(4): 1022-29.

[22] Song, L., Liu, F. Q., Zhu, C. Q., Li, A. M. (2019): Facile one-step fabrication of carboxymethyl cellulose based hydrogel for highly efficient removal of $\mathrm{Cr}$ (VI) under mild acidic condition. - Chemical Engineering Journal 369: 641-651.

[23] Tokunaga, T. K., Wan, J., Firestone, M. K. (2001): Chromium diffusion and reduction in soil aggregates. - Environmental Science \& Technology 35(15): 3169-74.

[24] Vega, F. A., Covelo, E. F., Andrade, M. L. (2006): Competitive sorption and desorption of heavy metals in mine soils: influence of mine soil characteristics. - Journal of Colloid \& Interface Science 298(2): 582-592.

[25] Wang, T., Liu, W., Xiong, L., Xu, N., Ni, J. (2013): Influence of pH, ionic strength and humic acid on competitive adsorption of $\mathrm{Pb}$ ( II), $\mathrm{Cd}$ ( II ) and $\mathrm{Cr}$ (III) onto titanate nanotubes. - Chemical Engineering Journal 215-216: 366-374. 
[26] Zeng, F., Ali, S., Zhang, H., Ouyang, Y., Qiu, B., Wu, F., Zhang, G. (2011): The influence of $\mathrm{pH}$ and organic matter content in paddy soil on heavy metal availability and their uptake by rice plants. - Environmental pollution 159(1): 84-91.

[27] Zhang, X., Tong, J., Hu, B. X., Wei, W. (2017): Adsorption and desorption for dynamics transport of hexavalent chromium (Cr (VI)) in soil column. - Environmental Science \& Pollution Research International 25(5): 1-10.

[28] Zhang, L. X., Tang, S. Y., He, F. X., Liu, Y., Mao, W., Guan, Y. T. (2019): Highly efficient and selective capture of heavy metals by poly(acrylic acid) grafted chitosan and biochar composite for wastewater treatment. - Chemical Engineering Journal 378: 122215. 